[Agr. Biol. Chem., Vol. 33, No. 9, p. 1257 1263, 1969]

\title{
Studies on Xylanase from Microorganisms
}

\section{Part II. Isolation and Selection of Xylanase-producing Microorganisms and the Identification of a New Species of Streptomyces}

\author{
By Hiroshi Izzuka and Toshiro Kawaminami \\ The Institute of Applied Microbiology, University of Tokyo \\ Received December 17, 1968
}

\begin{abstract}
As xylanase-producing microorganisms, 64 strains belonging to the genus Streptomyces were isolated from the barn-yard manures, silages and litters collected in Hokkaido district. Among these isolates the strain 102-1-4, which was found to be a new species under taxonomical studies and named Streptomyces xylophagus nov. sp., had the most outstanding ability for the enzyme production. In addition to the isolates, 38 strains of Streptomyces and 480 strains of flamentous fungi which have been preserved in our culture collection were also examined on their ability to produce the enzyme. 1) Among the strains of Streptomyces tested, only two strains, St. albogriseolus IAM 0031 and St. olivaceus IAM 0025 were found to have the ability, but their abilities were less than that of St. xylophagus nov. sp. 2) Out of 480 strains of fungi tested, Chaetomium, Schyzophyllum, Trametes, Echinodontium, Alternaria, Cepharosporium, Cercospora, Gibberella, Glomerella and Macrosporium produced the enzyme. Especially, Ch. trilaterale 2264 was the most excellent.
\end{abstract}

Many studies have been made on industrial uses of amylases and cellulase. However, only a few reports have been published on xylanase which are responsible for degradation of xylan, one of vegetable polysaccharides that exists widely, after starch and cellulose, in natural resources. ${ }^{\prime \prime}$ To date, some strains belonging to Bacillus, ${ }^{2,31}$ Aspergillus ${ }^{4 \sim 61}$ and a few other genera ${ }^{7,81}$ are reported to be able to secrete xylanase into culture media. The authors previously made public ${ }^{9 \prime}$ on the purification and some properties of xylanase from a new species of Streptomyces. This paper describes the isolation and the identification

1) Y. Tsuzuki, Saccharides, Iwanami, 1961, p. 187.

2) F.J. Simpson, Can.J. Microbiology, 2, 28 (1956).

3) $M$. Takahashi and Y. Hashimoto, Annual meeting of Japanese Agricultural and Chemical Society, 1957.

4) R. L. Whistler and E. Masak, J. Am. Chem. Soc., 77, 1241 (1955).

5) S. Fukui and M. Sato, Bull. Agr. Chem. Soc., 21, $392(1957)$. of the new species of Streptomyces. In addition, some fungi which have been preserved in our culture collection were studied on their ability to produce the enzyme.

\section{EXPERIMENTALS}

1. Isolation of microorganisms. On the agar plates containing xylan (obtained from Nutritional Biochemicals Corp.) as a sole source of carbon, a few drops of the suspension of each sample which was collected in the vicinity of Obihiro City in Hokkaido were spread and the plates were incubated at $28^{\circ} \mathrm{C}$. After certain periods of cultivation, microorganisms which formed clear-cut zones around their colonies were picked up as the strains having the enzymesecreting ability. The compositions of culture media used in the isolation procedures are as follows:

6) S. Fukui, J. Gen. Appl. Microbiol., 4, 39 (1958).

7) H. S $\phi$ rensen, Physiol. Plantarum, 5, 183 (1952).

8) K. Sumizu, M. Yoshikawa and S. Tanaka, $J$. Biochemistry, 50, 538 (1961).

9) H. Iizuka and T. Kawaminami, Agr. Biol. Chem., 29, 520 (1965). 


\begin{tabular}{|c|c|c|c|c|c|}
\hline & Xylan & $10.0 \mathrm{~g}$ & B. & Xylan & $10.0 \mathrm{~g}$ \\
\hline & Peptone & 10.0 & & Na-Glutamate & 5.0 \\
\hline & $\mathrm{K}_{2} \mathrm{HPO}_{4}$ & 1.0 & & $\mathrm{MgSO}_{4} \cdot 7 \mathrm{H}_{2} \mathrm{O}$ & 0.2 \\
\hline & $\mathrm{MgSO}_{4} \cdot 7 \mathrm{H}_{2} \mathrm{O}$ & 0.5 & & $\mathrm{KCl}$ & 0.1 \\
\hline & $\mathrm{KCl}$ & 0.5 & & $\mathrm{FeSO}_{4}$ & 0.01 \\
\hline & Water & 1.0 litre & & Water & 1.0 litre \\
\hline & $\mathrm{pH}$ & 6.0 & & $\mathrm{pH}$ & 7.2 \\
\hline C. & Xylan & $10.0 \mathrm{~g}$ & D. & Xylan & $10.0 \mathrm{~g}$ \\
\hline & Asparagine & 3.0 & & $\mathrm{NaNO}_{3}$ & 2.0 \\
\hline & $\mathrm{K}_{2} \mathrm{HPO}_{4}$ & 5.0 & & $\mathrm{~K}_{2} \mathrm{HPO}_{4}$ & 1.0 \\
\hline & $\mathrm{MgSO}_{4} \cdot 7 \mathrm{H}_{2} \mathrm{O}$ & 2.0 & & $\mathrm{MgSO}_{4} \cdot 7 \mathrm{H}_{2} \mathrm{O}$ & 0.5 \\
\hline & Water & 1.0 litre & & $\mathrm{KCl}$ & 0.5 \\
\hline & $\mathrm{pH}$ & 6.8 & & $\mathrm{FeSO}_{4}$ & 0.01 \\
\hline & & & & Water & 1.0 litre \\
\hline & & & & $\mathrm{pH}$ & 6.0 \\
\hline
\end{tabular}

2. Microorganisms tested. All strains tested in this paper were subcultured from the culture collection of our laboratory except 64 strains of Streptomyces newly isolated from the above-mentioned sources. Table I is a list of genera and number of the strains tested.

TABle I. LIST OF MICROORganisms Tested FOR XYlanase Production

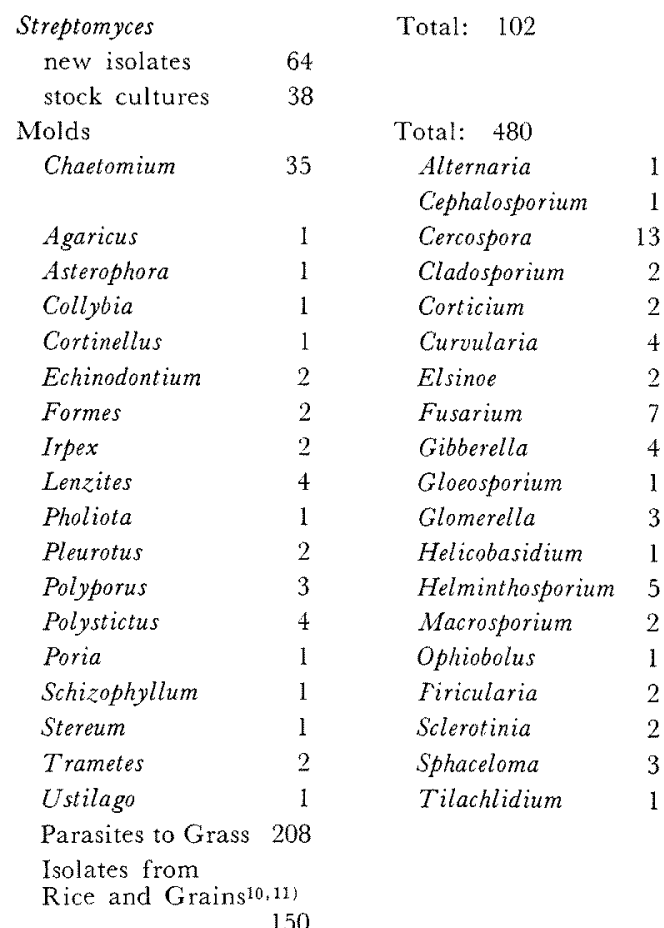

3. Assay of xylanase activity. Streptomyces strains were grown at $30^{\circ} \mathrm{C}$ in the medium $\mathrm{C}$ with shaking. After 3 days cultivation, the broth was filtrated through Toyo No. 2 filter paper to obtain clear filtrate, which was used for enzyme assay. The screening tests for fungi were carried out by almost the same methods as employed in Streptomyces strains except for their culture medium. The medium used for fungi was composed of $7 \%$ wheat bran and $0.1 \%$ yeast extract. One $\mathrm{ml}$ of culture filtrate of each test strain was added to $5 \mathrm{ml}$ of $0.5 \%$ xylan solution ( $\mathrm{pH} 6.2$ for Streptomyces and $\mathrm{pH} 4.0$ for fungi). After incubation for $15 \mathrm{~min}$ at $55^{\circ} \mathrm{C}$, the reaction was stopped by pouring the mixture into $10 \mathrm{ml}$ of Somogyi's reagent $A$ solution, and the amount of reducing sugar produced was determined by Somogyi's method ${ }^{12}$ as xylose. Furthermore, the composition of the reducing sugars was checked by paper chromatographies using $n$-propanol : ethylacetate: water $(6: 1: 3)$ and pyrimidine : ethylacetate : water $(8: 2: 1)$ as solvents.

\section{RESULTS AND DISCUSSIONS}

\section{Isolation and selection of xylanase-producing strains}

From 101 samples collected in Hokkaido, 64 strains were found to form clear-cut zones around their colonies and all of which belonged to Genus Streptomyces. Bacteria and fungi grew also on the agar plates, but they did not show any clear-cut zone. The typical clear-cut zones on the agar plates are shown in Fig. 1. The culture filtrates were checked whether they had actually the xylanase activities by introducing them into the xylan solution. The results are shown in Table II, indicating that No. 102-1-4 was the most potent strain. The reducing sugars in Table II were found to be composed of xylose and xylo oligosaccharides by chromatography. In these isolation and selection procedures, Streptomyces strains were obtained from all sources as shown in Table III, but most of the isolates

10) H. Tizuka, J. Gen. Appl. Microbiol., 3, 146 (1957).

11) H. lizuka, ibid., 4, 108 (1958).

12) T. Kobayashi and T. Tabuchi, J. Agr. Chem. Soc. Japan, 28, 171 (1954). 


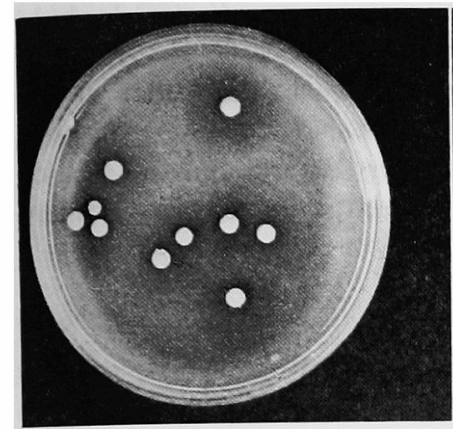

10-3-1

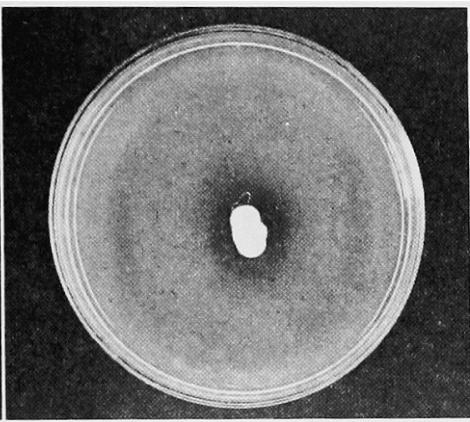

15-5-1

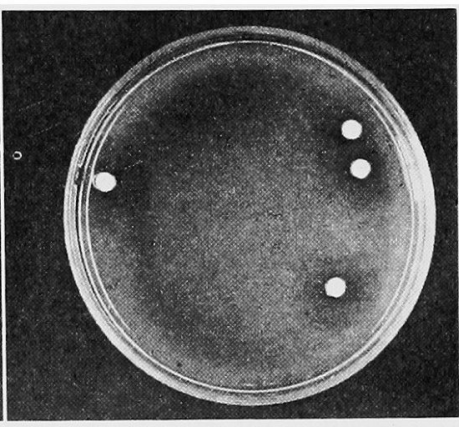

102-1-4

FIG. 1. Typical Clear-cut Zones on the Xylan Agar Plates. Photographed after 3 days cultivation at $28^{\circ} \mathrm{C}$.

Table II. Xylanase Activity of the Culture Filtrates of Streptomyces Strains NEWLY ISOLATED FROM VARIOUS SOURCES

\begin{tabular}{|c|c|c|c|c|c|c|c|c|c|c|c|}
\hline Strain & Source & $\begin{array}{l}\text { Reducing } \\
\text { sugar (mg) }\end{array}$ & Strain & Source & $\begin{array}{l}\text { Reducing } \\
\text { sugar }(\mathrm{mg})\end{array}$ & Strain & Source & $\begin{array}{l}\text { Reducing } \\
\text { sugar (mg) }\end{array}$ & Strain & Source & $\begin{array}{l}\text { Reducing } \\
\text { sugar (mg) }\end{array}$ \\
\hline $31-2-1$ & $\mathrm{BM}$ & 0.46 & $44-4-7$ & $\mathrm{BM}$ & 0.92 & $100-4-1$ & $\mathrm{BM}$ & 4.01 & $10-4-2$ & SG & 3.04 \\
\hline $34-3-1$ & $\mathrm{BM}$ & 5.31 & $44-5-2$ & $\mathrm{BM}$ & 0.43 & $100-4-2$ & $\mathrm{BM}$ & 4.07 & $11-3-1$ & SG & 0.81 \\
\hline $34-3-4$ & $\mathrm{BM}$ & 4.31 & $53-1-1$ & $\mathrm{BM}$ & 4.07 & $102-1-1$ & $\mathrm{BM}$ & 2.05 & $11-3-2$ & SG & 0.75 \\
\hline $34-3-5$ & $\mathrm{BM}$ & 3.80 & $53-3-2$ & $\mathrm{BM}$ & 3.66 & $102-1-2$ & $\mathrm{BM}$ & 2.61 & $49-5-1$ & $\mathrm{SG}$ & 1.13 \\
\hline $34-3-6$ & $\mathrm{BM}$ & 3.23 & $53-4-2$ & $\mathrm{BM}$ & 2.32 & $102-1-3$ & $\mathrm{BM}$ & 0.94 & $49-5-2$ & SG & 3.66 \\
\hline $34-5-1$ & $\mathrm{BM}$ & 4.46 & $53-4-3$ & $\mathrm{BM}$ & 0.67 & $102-1-4$ & $\mathrm{BM}$ & 6.95 & $42-3-1$ & $\mathrm{SC}$ & 1.56 \\
\hline $34-5-2$ & $\mathrm{BM}$ & 5.25 & $53-4-4$ & $\mathrm{BM}$ & 1.40 & $102-3-1$ & $\mathrm{BM}$ & 4.45 & $42-3-2$ & SC & 1.70 \\
\hline $36-4-1$ & $\mathrm{BM}$ & 1.75 & $53-5-3$ & $\mathrm{BM}$ & 2.18 & $102-3-2$ & $\mathrm{BM}$ & 5.07 & $72-3-1$ & $\mathrm{SC}$ & 3.02 \\
\hline $36-5-1$ & $\mathrm{BM}$ & 3.91 & $53-5-4$ & $\mathrm{BM}$ & 2.61 & $102-4-1$ & $\mathrm{BM}$ & 4.31 & $72-3-2$ & $\mathrm{SC}$ & 2.86 \\
\hline $44-1-1$ & $\mathrm{BM}$ & 1.05 & $53-5-5$ & $\mathrm{BM}$ & 1.70 & $102-4-2$ & $\mathrm{BM}$ & 4.18 & $106-3-1$ & SP & 4.85 \\
\hline $44-1-2$ & BM & 0.16 & $53-5-6$ & $\mathrm{BM}$ & 1.27 & $102-4-4$ & $\mathrm{BM}$ & 5.28 & $106-3-2$ & SP & 2.64 \\
\hline $44-3-1$ & $\mathrm{BM}$ & 0.67 & $78-1-2$ & BM & 0.57 & $102-5-1$ & BM & 3.83 & $106-3-3$ & SP & 3.02 \\
\hline $44-4-1$ & $\mathrm{BM}$ & 1.11 & $78-4-1$ & $\mathrm{BM}$ & 0.27 & 129-3-1 & $\mathrm{BM}$ & 0.57 & $15-5-1$ & $\mathrm{~L}$ & 5.31 \\
\hline $44-4-4$ & $\mathrm{BM}$ & 3.69 & $83-3-3$ & $\mathrm{BM}$ & 0.97 & $10-3-1$ & SG & 5.42 & $15-5-2$ & L & 0.84 \\
\hline $44-4-5$ & $\mathrm{BM}$ & 2.59 & $83-3-4$ & $\mathrm{BM}$ & 2.86 & $10-3-2$ & SG & 4.15 & $85-3-1$ & $\mathrm{~L}$ & 3.10 \\
\hline $44-4-6$ & $\mathrm{BM}$ & 0.65 & $100-3-3$ & $\mathrm{BM}$ & 1.05 & $10-4-1$ & SG & 4.10 & $85-4-1$ & $\mathrm{~L}$ & 3.83 \\
\hline
\end{tabular}

The xylanase activity was determined as follows: $1 \mathrm{ml}$ of culture filtrate of each test strain was added to $5 \mathrm{ml}$ of $0.5 \%$ xylan solution ( $\mathrm{pH} 6.2$, adjusted with $\mathrm{M} / 30$ phosphate buffer). After incubation for $15 \mathrm{~min}$ at $55^{\circ} \mathrm{C}$, the reducing sugar was determined by Somogyi's method. The xylanase activity in the table is expressed by the amount of reducing sugar produced.

BM: barn-yard manure, SG: grass silage, SP: potato silage, SC: corn silage, L: litter.

TABle III. Number OF ISOLATES OF STREPtomyces AND THEIR SOURCES

Source

Barnyard Manure (BM)

Silage $\begin{cases}\text { Grass Silage } & (\mathrm{SG}) \\ \text { Corn Silage } & (\mathrm{SC}) \\ \text { Potato Silage } & (\mathrm{SP})\end{cases}$ Litter (L)

Total

\section{No. of} samples

24
57
8
7
5
101

No. of strains isolated 45 8 4 3 4 64 came to hand from barn-yard manures. This fact means that Streptomyces strains might play an important role in degradation of vegetable fibres and formation of humus of soil.

\section{Xylanase production by the stock culture of Streptomyces \\ In accordance with the results of the above}


experiments, some Streptomyces species in our culture collection were tested on their ability to produce the enzyme. The results are shown in Table IV In general, the strains had low

Table IV. Xylanase Production by Stock CULTURE OF STREPTOMYCES

\begin{tabular}{|c|c|c|}
\hline Species & Growth & $\begin{array}{c}\text { Enzyme } \\
\text { activity } \\
\text { (mg) }\end{array}$ \\
\hline St. albogriseolus IAM 0031 & H & 4.6 \\
\hline olivaceus IAM 0025 & H & 4.1 \\
\hline fradiae IAM 0088 & $+H$ & \pm \\
\hline bobiliae IAM 0002 & H & \pm \\
\hline coelicolor IAM 0032 & 卅 & - \\
\hline viridochromogenes IAM 0066 & $H$ & - \\
\hline flaveolus LAM 0033 & H & - \\
\hline californicus IAM 0003 & + & - \\
\hline cinamonensis IAM 0020 & + & - \\
\hline flavovirens IAM 0069 & H & - \\
\hline phaeochromogenus IAM 0026 & $H$ & - \\
\hline virginiae IAM 0056 & + & - \\
\hline antibioticus IAM 0076 & $H$ & - \\
\hline griseolus $1 \mathrm{AM} 0021$ & + & - \\
\hline griseoluteus IAM 0060 & + & - \\
\hline griseoruber IAM 0110 & + & - \\
\hline flavus IAM 0083 & + & - \\
\hline griseus IAM 0084 & + & - \\
\hline halstedii IAM 0048 & + & - \\
\hline aureofaciens IAM 0087 & + & - \\
\hline albus IAM 0057 & - & - \\
\hline bikiniensis IAM 0019 & - & - \\
\hline hygroscopicus IAM 0072 & - & - \\
\hline lipmanii IAM 0036 & - & - \\
\hline aureus IAM 0092 & - & - \\
\hline flavochrogenes IAM 0059 & - & - \\
\hline lavendulae IAM 0009 & - & - \\
\hline luteoverticillatus IAM 0049 & - & - \\
\hline microflavus IAM 0010 & - & - \\
\hline parvus IAM 0013 & - & - \\
\hline rimosus IAM 0014 & - & - \\
\hline roseochromogenus IAM 0027 & - & - \\
\hline scabies IAM 0015 & - & - \\
\hline venezuelae IAM 0017 & - & - \\
\hline vinaceus IAM 0042 & - & - \\
\hline$N$. astroides $\mathrm{IAM}$ & - & - \\
\hline N. gardneri IAM 0105 & - & - \\
\hline N. narashinoensis IAM 0113 & - & - \\
\hline
\end{tabular}

The enzymatic activity was determined and expressed as shown in Table II. xylanase activity, except St. albogriseolus IAM 0031 and St. olivaceus IAM 0025. However, their abilities were lower than that of the newly isolated strain No. 102-1-4. No clear relationship between the taxonomical position and action to xylan was noted in the experiments.

3. Xylanase production by various kinds of fungi Out of 480 strains of fungi tested, only 19 strains secreted the enzyme into culture broth as shown in Table $\mathrm{V}$ The enzyme was found more widely among the strains belonging to Genus Chaetomium than other genera of fungi tested; 10 out of 35 strains of Chaetomium tested showed the enzyme activity and Ch. trilaterale 2264 was found to be the most prominent strain. Among Basidiomycetes, Schzophyllum

Table V. Xylanase Production by Various KINDS OF FUNGI

\begin{tabular}{lc}
\multicolumn{1}{c}{ Species } & $\begin{array}{c}\text { Enzyme activity } \\
\text { (mg) }\end{array}$ \\
Chaetomium atrobrunneum 2101 & 1.35 \\
Chaetomium aureum 2103 & 1.24 \\
Chaetomium aureum 2107 & 1.35 \\
Chaetomium brasilliense 2114 & 1.21 \\
Chaetomium elatum 2126 & 0.90 \\
Chaetomium indicum 2222 & 0.81 \\
Chaetomium indicum 2236 & 0.62 \\
Chaetomium tolulosum 2260 & 0.86 \\
Chaetomium trilaterale 2261 & 1.75 \\
Chaetomium trilaterale 2264 & 6.08 \\
Alternaria kikuchiana 5005 & 0.33 \\
Cephalosporium acremonium 5027 & 1.40 \\
Cercospora melonis 5046 & 1.40 \\
Gibberella sabinetti 8049 & 1.37 \\
Glomerella cingulata 8050 & 1.43 \\
Macrosporium bataticola 5014 & 1.67 \\
Echinodontium tsugicola 9010 & 1.37 \\
Schizophyllum commune 9006 & 3.96 \\
Trametes pini 9007 & 2.07
\end{tabular}

One $\mathrm{ml}$ of culture filtrate of each test strain was added to $5 \mathrm{ml}$ of $0.5 \%$ xylan solution $(\mathrm{pH} 4.0$, adjusted with acetate buffer). After incubation for 15 min at $55^{\circ} \mathrm{C}$, the reducing sugar was determined by Somogyi's method. The xylanase activity in the table is expressed by the amount of reducing sugar produced. 
commune 9006, Trametes pini 9009, and Echinodontium tsugicola had the enzyme-producing ability. As long as Fungi imperfecti and Plant pathogens are concerned, Alternaria, Cephalosporium, Cercospora, Gibberella, Glomerella and Macrosporium showed the ability. However, their abilities were lower than that of Chaeto-

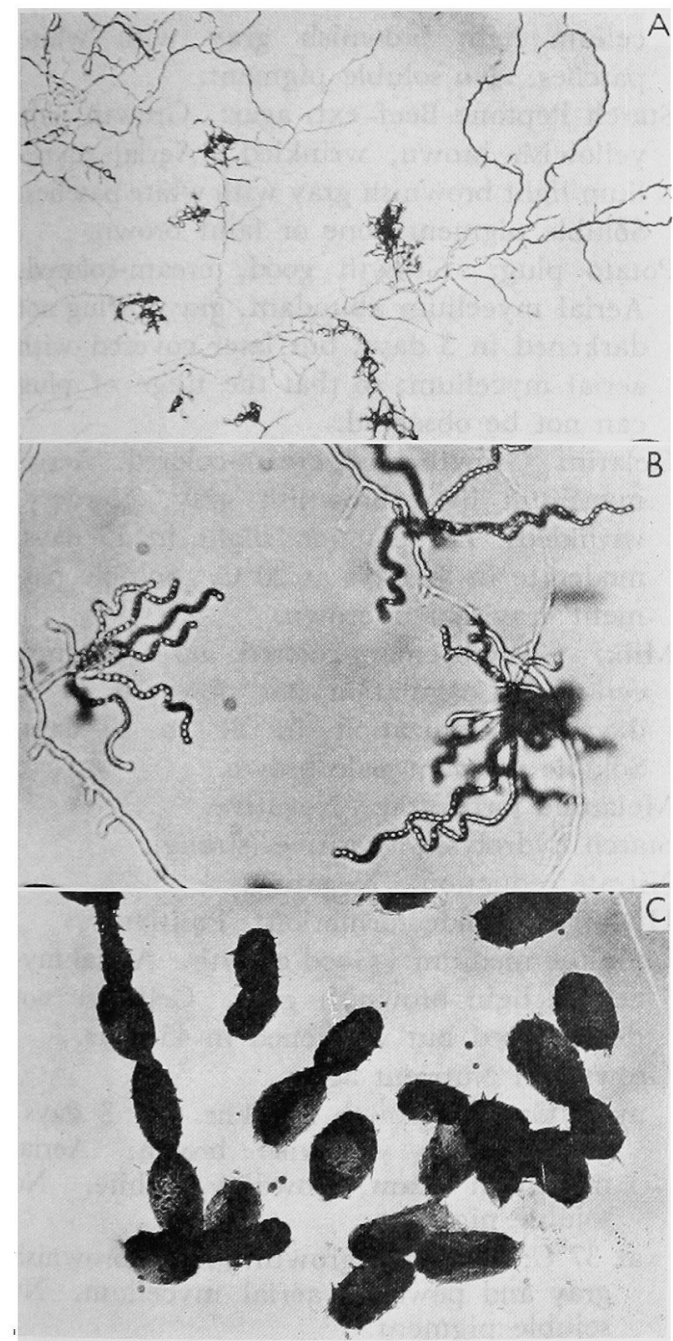

Fig. 2. Microscopic Observation of the Sporophore and the Spore of Strain 102-1-4.

A, B: sporophore, C: spore (under electron microscopy) mium trilaterale 2264. Plant parasites and the isolates from rice and grains did not produce the enzyme. Sumizu et al. ${ }^{81}$ reported that rice-blight organisms secreted the enzyme, but neither Piricularia oryzae 5016 nor 5017 showed the ability in this experiment.

\section{Identification of Streptomyces sp. No. 102-1-4}

This organism shows a number of identifying characteristics which distinguishes it from other allied species of Streptomyces. Sporophores are monopodially branched, producing open spirals and the surface of the conidial spore is spiny under electron microscopy as shown in Fig. 2. The growth is usually colourless to yellow and the pigment of the mycelium generally does not diffuse into culture media; aerial mycelium changes to various shades of gray, ranging from light gray to mouse gray according to the media. No coagulation of milk with slow peptonization; the proteolytic action on gelatin is weak and liquefaction starts only after the 15th day of incubation. Melanine formation is negative. Starch is readily hydrolized. Nitrate is not reduced to nitrite; hydrogen sulfide formation is positive. Optimum temperature for growth is at $37^{\circ} \mathrm{C}$, and good growth is observed at $45^{\circ} \mathrm{C}$, too. Judging from the morphological, cultural and physiological characteristics described above, the strain 102-1-4 should be included into Series Cinereus ${ }^{131}$ and closely resembles St. parvullus ${ }^{14)}$ Waksman and Gregory with regard to the colors of the vegetative and aerial mycelia, shape of sporophore, mode of growth in some media, liquefaction of gelatin, peptonization of milk and melanine formation; but it showed marked differences in the reduction of nitrate and soluble pigmentation in some media. Especially, it differs from St. parvullus Waksman and Gregory in the surface of conidial spore; that of the strain

13) S. A. Waksman, The Actinomycetes, Vol. 2, The Williams and Wilkins Co., 1961, p. 117.

14) S. A. Waksmann and F. J. Gregory, Antibiotics and Chemotherapy, 4, 1050 (1954). 
$102-1-4$ is spiny, while that of St. parvullus is smooth. The strain $102-1-4$ is distinguished in its good growth at $45^{\circ} \mathrm{C}$. Other known species in Series Cinereus such as St. craterifer ${ }^{15}$ Waksman and St. cellulosae ${ }^{16}$ Jensen are completely different from the strain 102-1-4 in the morphological characteristics, liquefaction of gelatin, peptonization of milk, hydrogen sulfide formation and reduction of nitrate. Therefore, the strain $102-1-4$ is considered to be a new species and it has been named Streptomyces xylophagus nov. sp. Iizuka et Kawaminami after its ability to produce xylanase.

\section{DESCRIPTION}

Streptomyces xylophagus nov. sp.

xylo Gr. n. xylon wood; phagus Gr. v. phagein devour: xylophagus M. L. adj. wooddevouring

Type strain: 102-1-4; the strain was deposited to IAM Culture Collection, The University of Tokyo.

Morphology: Sporophores monopodially branched, producing open spirals. Spores spherical to oval, spiny. 0.7 to 1.0 by 0.8 to $1.2 \mu$.

Sucrose Nitrate agar: Growth thin, colorless. Aerial mycelium abundant, at first white, later becoming brownish gray, with white puffs. No soluble pigment.

Glucose Asparagine agar: Growth pale yellowish brown, later dull orange. Aerial mycelium abundant, powdery, light brownish gray, with white puffs. Soluble pigment faint reddishbrown.

Glycerol Asparagine agar: Growth pale yellowish brown, later dull orange. Aerial mycelium abundant, powdery light brownish gray with white puffs, wrinkled at concentric zone. Soluble pigment none or faint brown.

15) S. A. Waksman, Actinomycetes and Their Aritibiotics, Baltimore, 1953, p. 105.

16) H. L. Jensen, Soil Science, 30, 65 (1930).
Nutrient agar: Growth colorless, smooth. Aerial mycelium at first white, becoming brownish gray with age. No soluble pigment.

Glycerol Calcium Malate agar: Growth moderate, colorless. Aerial mycelium scant, whitish gray, with white patches, No soluble pigment.

Starch agar: Growth colorless. Aerial mycelium light brownish gray with white patches. No soluble pigment.

Starch Peptone Beef ext. agar: Growth pale yellowish brown, wrinkled. Aerial mycelium light brownish gray with white patches. Soluble pigment none or faint brown.

Potato plug: Growth good, cream-colored. Aerial mycelium abundant, gray. Plug not darkened in 3 days, but later covered with aerial mycelium; so that the tinge of plug can not be observed.

Gelatin: Growth good, cream-colored. Aerial mycelium light brownish gray, powdery, wrinkled. Liquefaction slight in 15 days, moderate in 30 days at $20^{\circ} \mathrm{C}$. Soluble pigment grayish red brown.

Milk: Growth cream-colored, no aerial mycelium. Coagulation not observed in 30 days. Peptonization in 21 to 30 days. Soluble pigment pale brown.

Melanine formation: Negative.

Starch hydrolysis: Positive (strong).

Nitrate reduction: Negative.

Hydrogen sulfide formation: Positive.

Cellulose medium: Good growth. Aerial mycelium light brownish gray. Cellulose not decomposed but weakened in 45 days.

Growth on Nutrient agar:

at $20^{\circ} \mathrm{C}$; No growth in $24 \mathrm{hr}$. In 3 days growth pale yellowish brown. Aerial mycelium scant, powdery, white. No soluble pigment.

at $37^{\circ} \mathrm{C}$; The best growth. Light brownish gray and powdery aerial mycelium. No soluble pigment.

at $45^{\circ} \mathrm{C}$; Good growth, cream-colored, some wrinkled. Aerial mycelium light brownish gray, powdery.

at $55^{\circ} \mathrm{C}$; No growth. 
Carbon utilization: Glucose, Galactose, Man- Habitat: Barn-yard manure, Hokkaido, Japan; nose, Fructose, Rhamnose, Xylose, L-Arabinose, Ribose, Maltose, Treharose, Cellobiose, Inositol, utilized very well. Sucrose utilized a little in 5 days, but in 7 days utilized as well as Glucose. Raffinose, Dultit, collected in November, 1963.

Acknowledgement. The authors wish to thank Mr. D. Okuno for his kind cooperation in taking electron microscopic photographs of $S t$. xylophagus nov. sp. Inuline, not utilized. 